\title{
The plant defensin gene AtPDF2.1 mediates ammonium metabolism by regulating glutamine synthetase activity in Arabidopsis thaliana
}

\author{
Junyue Yao ${ }^{1}$, Jin-Song Luo ${ }^{1,2^{*}}$, Yan Xiao ${ }^{1}$ and Zhenhua Zhang ${ }^{1,2^{*}}$ (D)
}

\begin{abstract}
Background: In plants, ammonium metabolism is particularly important for converting absorbed nitrogen into amino acids. However, the molecular mechanism underlying this conversion remains largely unknown.

Results: Using wild type Arabidopsis thaliana (Col-0) and AtPDF2.1 mutants (pdf2.1-1 and pdf2.1-2), we found that the small cysteine-rich peptide AtPDF2.1, a plant defensin, is involved in regulating ammonium metabolism in the shoot. Ammonium significantly induced the expression of AtPDF2.1 in the shoot and root, particularly in root xylem vascular bundles, as demonstrated by histochemical analysis. Subcellular localization analysis revealed that AtPDF2.1 was localized to the cell wall. Ammonium concentration was higher in the shoot of mutants than in the shoot of Col-0, but no differences were found for total nitrogen content, root ammonium concentration, and the expression of the ammonium transporter gene AtAMT2.1. The activity of glutamine synthetase was significantly decreased in mutants, and the glutamine synthetase family genes GLN1.3 and GLN1.5 were significantly downregulated in mutants compared to Col-0. The activity of nitrate reductase showed no difference between mutants and Col-0.

Conclusions: Overall, these data suggest that AtPDF2.1 affects ammonium metabolism by regulating the expression of GLN1.3 and GLN1.5 through a yet unidentified mechanism.
\end{abstract}

Keywords: Ammonium metabolism, Arabidopsis thaliana, GLN1.3, GLN1.5, PDF2.1, Plant defensins

\section{Background}

Plant defensins (PDFs) are small cysteine-rich peptides, usually composed of an $\mathrm{N}$-terminal signal peptide, Cterminal variable region, and cysteine-rich domain $[1,2]$. Nuclear magnetic resonance analysis of the structure and homology of RsAFP1 in radish revealed that this defensin had a common cysteine-stabilized alpha beta conformation with four disulfide bonds on an alpha helix in reverse parallel with three beta angles [3]. Plant defensins are ubiquitous in plants and animals and mediate innate nonspecific immune responses [4]. Most of the defensins identified in plants have broad-spectrum antimicrobial activities, inhibiting amylase and blocking

\footnotetext{
* Correspondence: 0609020317@163.com; zhzh1468@163.com

1Southern Regional Collaborative Innovation Center for Grain and Oil Crops

in China, College of Resources and Environmental Sciences, Hunan

Agricultural University, Changsha, China

Full list of author information is available at the end of the article
}

ion channels $[2,5]$. Two families of PDFs have been reported in Arabidopsis thaliana. The first family contains seven members with high homology (PDF1.1, PDF1.2a, PDF1.2b, PDF1.2c, PDF1.3, PDF1.4, and PDF1.5), five of which are very similar (PDFs 1.1 to 1.3). In addition, the predicted mature structures of PDF1.2a, b, and $c$ are similar. The members of the second family (PDFs 2.1 to 2.6) are also very close. While PDFs 2.1, 2.3, and 2.6 appeared in a tandem array, PDF 2.2 and the other genes were not in the same branch [2]. Previous studies on different PDF genes (PDF1.1, 1.2, 2.1, 2.2, and 2.3) have shown their organ-specific expression patterns $[2,6]$. Recent studies have evidenced that PDFs are also involved in abiotic stress response, as their expression levels are induced by cold, drought, and heavy metal stresses [7-9], and PDF2.3 is likely related to potassium ion homeostasis [10]. Latest research revealed that PDFs

(c) The Author(s). 2019 Open Access This article is distributed under the terms of the Creative Commons Attribution 4.0 International License (http://creativecommons.org/licenses/by/4.0/), which permits unrestricted use, distribution, and 
mediate cadmium tolerance and accumulation in rice and A. thaliana [11, 12].

Small peptides can be used as signal molecules to regulate nitrogen $(\mathrm{N})$ response and stress adaptation $[13$, 14]. Small C-terminal-encoded peptides (CEPs) [15], for instance, are produced by $\mathrm{N}$-starved roots and translocated to the shoot where they interact with leucine-rich repeat receptor kinase CEP receptor 1/2 (CEPR1/2) [13]. Rhizobium-induced xylem mobile CLAVATA3/EMBRYO SURROUNDING REGION-RELATED (CLE) peptides have been shown to inhibit nodulation in legumes [16]. Although it is not clear whether PDFs interact with $\mathrm{N}$ in $A$. thaliana, we hypothesize that small PDFs may also function as signal molecules in regulating $\mathrm{N}$ metabolism.

$\mathrm{N}$ is an essential mineral element for plants and plays an important role in plant growth and development. It is not only a component of nucleic acids, amino acids, and proteins; it also participates in carbon assimilation during photosynthesis as a component of chlorophyll, and an interaction between $\mathrm{N}$ and phosphorus has been reported in rice [17]. Nitrate and ammonium are the main forms of $\mathrm{N}$ uptake by plants. When nitrate is absorbed by plants, a part of it is directly transported to the aerial parts or stored in vacuoles in the root cells, and another part is converted to ammonium or integrated into amino acids for metabolism or transportation to the aerial parts [18].

In agricultural production, the application of $\mathrm{N}$ fertilizer generally has a substantial yield-increasing effect $[19,20]$. However, the low utilization rate of $\mathrm{N}$ fertilizer not only leads to waste of resources and environmental pollution, but also seriously threatens human health. Therefore, it is very important to improve plant $\mathrm{N}$ use efficiency (NUE) and to reduce environmental pollution. Transport from soil to root and from root to shoot and other plant organs involves many processes such as $\mathrm{N}$ uptake, assimilation, transport, and reuse. $\mathrm{N}$ assimilation is not only the most critical step in these processes, but also one of the most important limiting factors for plant growth. Therefore, improving $\mathrm{N}$ assimilation efficiency is an important aspect of improving plants' NUE.

In several plant species, a part of the nitrate absorbed by the roots is assimilated in the roots, but most of it is transported to the shoot and then assimilated. Nitrate is first reduced to nitrite by nitrate reductase (NR) in the cell cytoplasm, and previous studies have shown that the activity of NR is regulated by $14-3-3$ proteins, protein kinases, proteases, and protein phosphatases [21]. This enzyme is regulated by NR [NADH] proteins (NIAs), and NIA2, rather than NIA1, regulates the NR activity in A. thaliana $[18,22]$. The reduction of nitrite to ammonium by nitrite reductase requires $\mathrm{NAD}(\mathrm{P}) \mathrm{H}$. In addition, the assimilation of ammonium to amino acids via the glutamine synthetase (GS)/NADH-glutamine oxoglutarate transaminase (NADH-GOGAT) cycle also requires ATP and NADH or reduced ferredoxin [18]. Recent studies have shown that NIN-like protein transcription factors are key regulators of nitrate-induced $N R$ gene expression and that NIN-like protein transcription factors may be in harmony with nitrateinduced expression of other nitrate assimilation-related genes [23, 24].

The ammonium restored from nitrate or absorbed directly by the action of ammonium transporters (AMTs) is further reduced by nitrite reductase in the plastid and by GS in the plastid and cytoplasm [25] or assimilated into amino acids through the GS and GOGAT cycles. The main GS/GOGAT isozymes involved in these processes are GS2 and ferredoxin-dependent GOGAT (FeGOGAT) in the chloroplast, and GS1 and NADHGOGAT in the cytoplasm [26, 27]. The physiological functions of some GS1 isoenzymes in A. thaliana have been reported [28-30]. In this species, GLN1.1 and GLN1.4 showed high affinity for ammonium, while GLN1.2 and GLN1.3 showed low affinity [31]. At low concentrations, ammonium is assimilated by GLN1.1, GLN1.2, and GLN1.3, and they are functionally redundant [32]. Some studies in maize also pointed out that GLN1.4 could work on the re-assimilation of the released ammonium [33, 34]. In A. thaliana, GLN1.5 has not been detected at the transcription level [35] whereas GLN2-encoded GS has double targeting to leaf mitochondria and chloroplasts [36]. In addition to the major $\mathrm{N}$ assimilation, $\mathrm{N}$ re-assimilation also captures large amounts of ammonia through photorespiration in photosynthetic tissues and protein conversion during senescence or seed germination [37].

Glutamate metabolism is related to glutamate dehydrogenase $(\mathrm{GDH})$ activity, which catalyzes the interconversion of glutamate and 2-oxoglutarate. Recent studies in A. thaliana clearly showed that GDH plays a central role in amino acid decomposition under carbon deficiency, and the main physiological function of NADH-GDH is to provide 2-oxoglutarate for the tricarboxylic acid cycle [38, 39].

$\mathrm{N}$ assimilation is a reaction to internal and external clues of $\mathrm{N}$ metabolites such as amino acids, ammonium, and nitrates. Isozymes are regulated at the level of transcription, translation, and post-translational modification [40]. The regulation of $\mathrm{N}$ uptake and assimilation is also related to root development. Absorption is particularly dependent on root-related characteristics, because plants not only regulate their metabolism and gene expression through their roots, but also adjust their structure to optimize resource acquisition $[41,42]$. 
In a changing environment, a more comprehensive understanding of $\mathrm{N}$ assimilation and its regulation is of great importance to improve plant productivity. Therefore, it is necessary to strengthen basic research on reference species as well as on other plant species. In the present study, and by examining the molecular and genetic mechanism of $\mathrm{N}$ assimilation in A. thaliana, we explored the role of AtPDF2.1 on ammonium metabolism regulation.

\section{Results}

\section{AtPDF2.1 response to ammonium}

First, we conducted induction experiments on all members of the $P D F$ family genes to assess their responses to high nitrate, low nitrate, and ammonium. The results obtained for Col-0 hydroponically grown for $18 \mathrm{~d}$ under culture conditions, $\mathrm{N}$-starved for $3 \mathrm{~d}$, and then treated with $0.2 \mathrm{mM} \mathrm{KNO}{ }_{3}, 2.25 \mathrm{mM} \mathrm{KNO} 3,10 \mathrm{mM} \mathrm{KNO}$, or $1.125 \mathrm{mM} \mathrm{NH}_{4} \mathrm{NO}_{3}$ for $6 \mathrm{~h}$ before root sampling showed that PDF2.1 and PDF2.3 were induced by ammonium, particularly PDF2.1 (Fig. 1). To further verify if PDF2.1 was induced under pure ammonium growth conditions, we used the wild type Col-0 hydroponically grown for $18 \mathrm{~d}$ under culture conditions, $\mathrm{N}$-starved for $3 \mathrm{~d}$, and then treated with $2.25 \mathrm{mM} \mathrm{KNO}, 1.125 \mathrm{mM}\left(\mathrm{NH}_{4}\right)_{2} \mathrm{SO}_{4}$, or $1.125 \mathrm{mM} \mathrm{K}_{2} \mathrm{SO}_{4}$ for $6 \mathrm{~h}$ before shoot and root sampling. This experiment revealed that AtPDF2.1 was significantly induced under the ammonium treatment both in shoot and root (Fig. 2).

AtPDF2.1 is mainly expressed in the root vascular bundles and cotyledons and its protein is localized to the cell wall To elucidate the expression pattern of AtPDF2.1, we generated AtPDF2.1 promoter-driven $\beta$-glucuronidase (GUS) transgenic plants. PDF2.1 was expressed in the root, seedling, leaf, stem, silique, and flower, as determined by quantitative PCR analysis (Fig. 3a). We detected strong GUS signals in the leaves, cotyledons, and root vascular bundles (Fig. 3b-d). The cross-section GUS analysis showed strong expression in parenchyma cells of vascular xylem in the roots (Fig. 3e). To determine the subcellular localization of AtPDF2.1, we transformed A. thaliana plants with AtPDF2.1-mRFP using the $35 \mathrm{~S}$ promoter. The subcellular localization assays showed that the fluorescence signal was predominant in the cell wall of transformed plants (Fig. 4). These results indicated that AtPDF2.1 is localized to the cell wall.

\section{AtPDF2.1 affects the concentration of ammonium in shoots}

We first screened and identified the AtPDF2.1 mutants. Although the expression level of AtPDF2.1 in the mutants was significantly lower than that in the wild type, the expression of this gene was still detected. Therefore, we obtained two functional knock down mutants, $p d f 2.1-1$ and $p d f 2.1-2$ (Fig. 5). After transplantation, Col-0, pdf2.1-1, and pdf2.1-2 seedlings were cultured under normal conditions ( $1 / 4$ plant nutrient solution) for $18 \mathrm{~d}$ and then sampled and analyzed for differences in total $\mathrm{N}$ content, NUE, ammonium concentration, and gene expression of AMT2.1 between the selected AtPDF2.1 mutants and Col-0. Under normal conditions, ammonium concentrations were higher in $p d f 2.1-1$ and pdf2.1-2 shoots than in Col-0 shoots, but no significant differences were detected among roots (Fig. 6a, b). There were also no significant differences in nitrate concentrations in the shoots and roots of Col-0, pdf2.1-1, and pdf2.1-2 plants (Additional file 1: Figure S1). Protein AMT2.1 transports ammonium from the root to the shoot $[43,44]$. Under normal conditions, there was no difference in AtAMT2.1 expression in the roots of Col-0, $p d f 2.1-1$, and $p d f 2.1-2$ (Fig. 6d), indicating that AtPDF2.1 was not involved in ammonium transport from roots to shoots. The total $\mathrm{N}$ content and NUE of Col-0, $p d f 2.1-1$, and $p d f 2.1-2$ plants also showed no differences (Fig. 6e, f). These results suggested that AtPDF2.1 may affect the metabolism of ammonium in shoots.

AtPDF2.1 affects GS activity by regulating the expression of GLN1.3 and GLN1.5 in shoots

Although AtPDF2.1 had no effect on total N content, root ammonium concentration, and expression of AtAMT2.1, ammonium concentration was significantly higher in the shoots of mutant A. thaliana than in Col-0 shoots. Therefore, we hypothesized that AtPDF2.1 might participate in the regulation of ammonium metabolism in the shoot.

Under normal conditions, there was no difference in NR activity among the shoots of Col-0, pdf2.1-1, and pdf2.1-2, while GS activities in the shoots of $p d f 2.1-1$ and $p d f 2.1-2$ were significantly lower than in the shoot of Col-0. In addition, ammonium concentration in the shoots of $p d f 2.1-1$ and $p d f 2.1-2$ was higher than in Col0 shoots (Fig. 7). In pdf2.1 mutants, GLN1.3 and GLN1.5 were downregulated, but no effect was detected for other GLN family genes. Thus, AtPDF2.1 may affect the assimilation of ammonium into glutamine by regulating the expression of GLN1.3 and GLN1.5 (Fig. 8).

\section{AtPDF2.1 affects ammonium metabolism in shoots}

To examine which steps of ammonium metabolism are specifically affected by AtPDF2.1, we determined the concentrations of glutamine and glutamic acid, the activity of NADH-GOGAT, and the concentration of free amino acids. Glutamine concentrations in $p d f 2.1-1$ and pdf2.1-2 were lower than in Col-0, and NADH-GOGAT activity was also lower in the mutants than in Col-0 


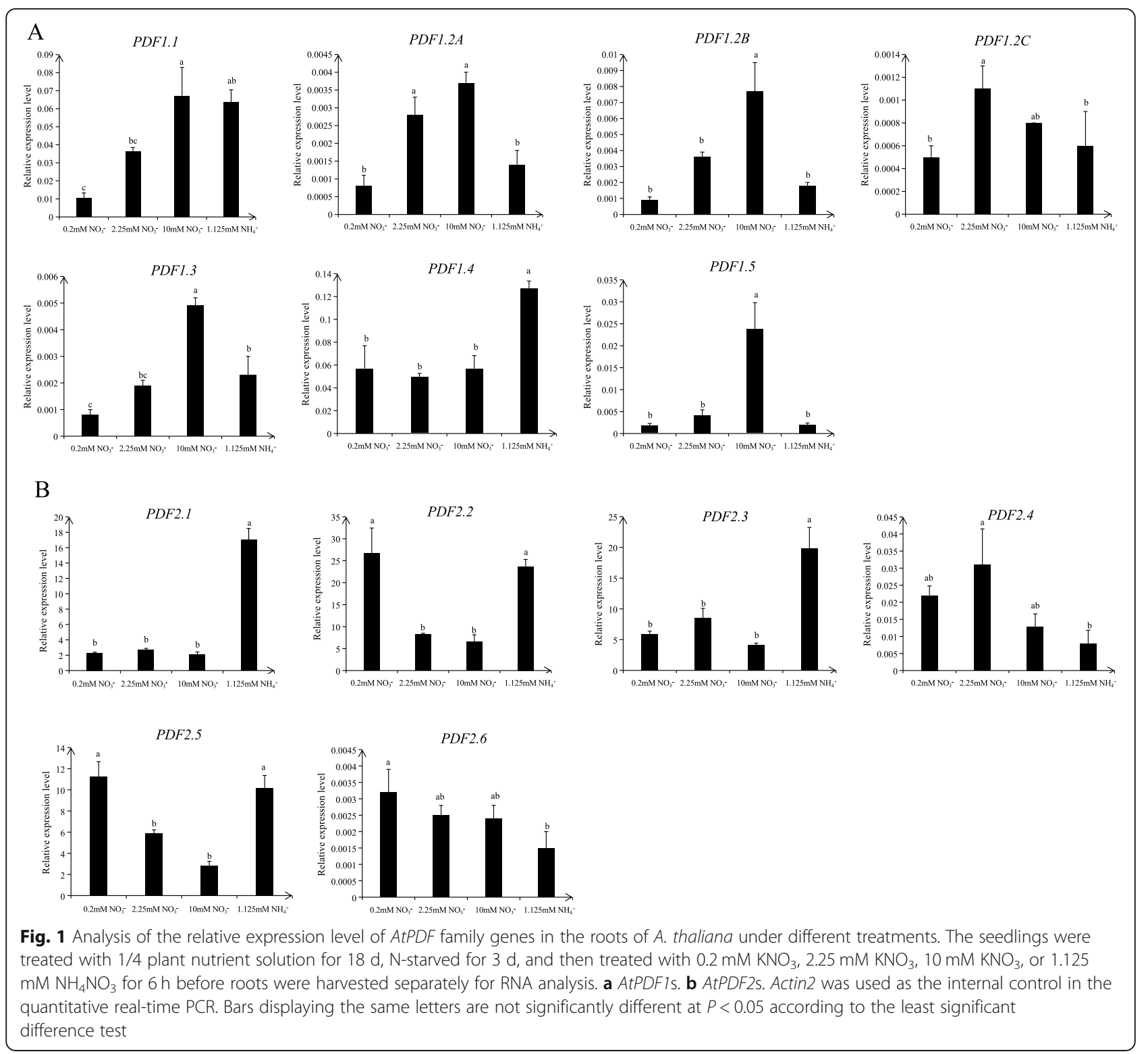

(Fig. 9a, b). Thus, the decreased GS activity in mutants might have affected subsequent metabolic pathways. There were no significant differences in the concentrations of glutamic acid and free amino acids among Col$0, p d f 2.1-1$, and $p d f 2.1-2$ (Fig. 9c, d), possibly due to the functional redundancy of GLN1.3 and GLN1.1 and extremely low expression of GLN1.5, leading to a dominant role of GLN1.2 [32, 34].

Overall, results suggest that AtPDF2.1 regulates the activity of GS by altering the expression of GLN1.3 and GLN1.5, leading to changes in ammonium assimilation in shoots. This alters glutamine concentration and NADH-GOGAT activity, thereby affecting the assimilation of ammonium.

\section{Discussion}

PDFs are small cysteine-rich peptides firstly found in wheat and barley seeds [45]. In A. thaliana, defensins are divided into two families, PDF1s and PDF2s. A previous study showed that AtPDF1.1 is involved in plants' response to biotic stress [46]. Other studies found that PDF1s increased zinc tolerance of plants and yeasts [9, 47, 48]. However, to our knowledge, the molecular mechanism of PDFs had not been clarified.

Some reports found that small peptides are associated with N. In $A$ thaliana under nitrate deficiency, the expression of CEP3 in roots increased by 10 -fold and $C E P 1$ expression in seedlings also increased; under ammonium restriction, CEP9 expression was inhibited [15]. 

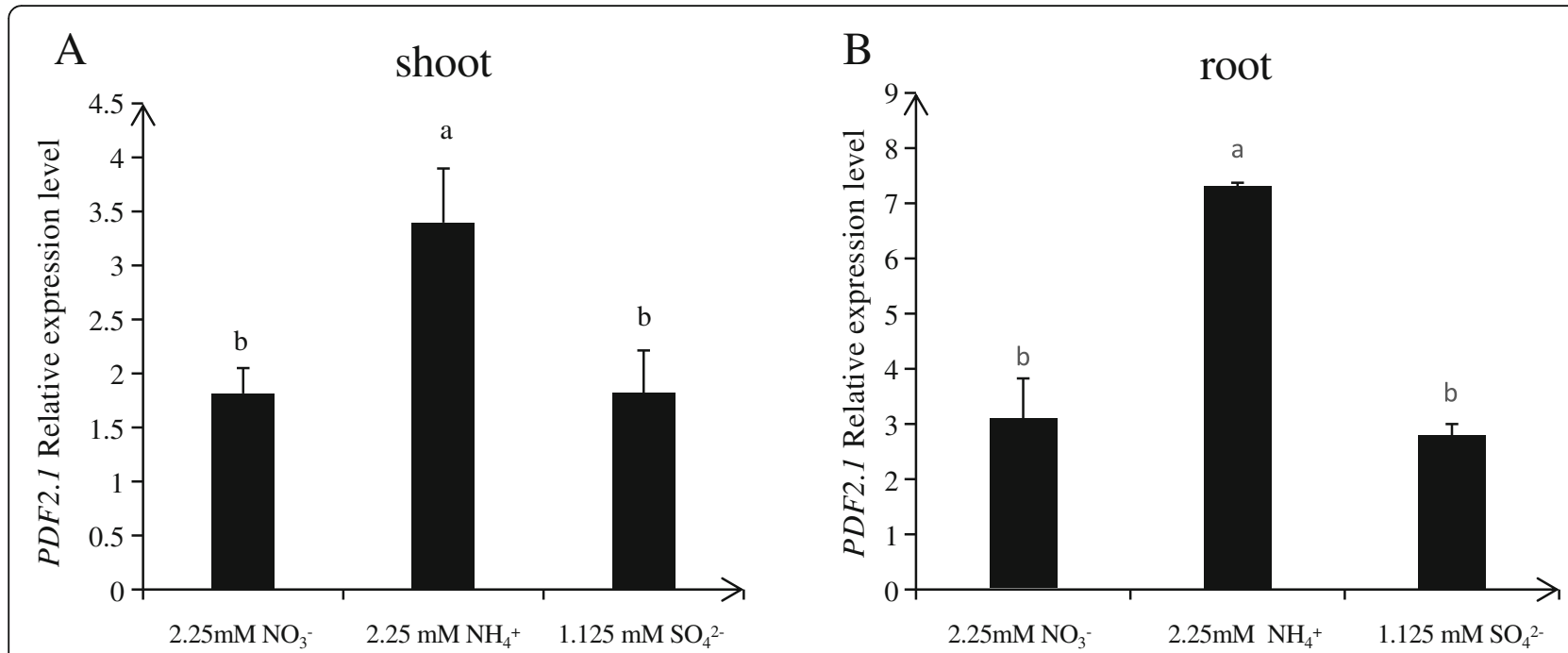

Fig. 2 AtPDF2.1 relative expression is significantly induced by ammonium. A. thaliana seedlings were treated with 1/4 plant nutrient solution for $18 \mathrm{~d}$ and then $\mathrm{N}$-starved for $3 \mathrm{~d}$. The seedlings were treated with $2.25 \mathrm{mM} \mathrm{KNO}_{3}, 1.125 \mathrm{mM}\left(\mathrm{NH}_{4}\right)_{2} \mathrm{SO}_{4}$, and $1.125 \mathrm{mM} \mathrm{K}_{2} \mathrm{SO}_{4}$ for $6 \mathrm{~h}$ before roots and shoots were harvested separately for RNA analysis. a shoot. $\mathbf{b}$ root. Actin2 was used as an internal control. Bars displaying the same letter are not significantly different at $P<0.05$ according to the least significant difference test
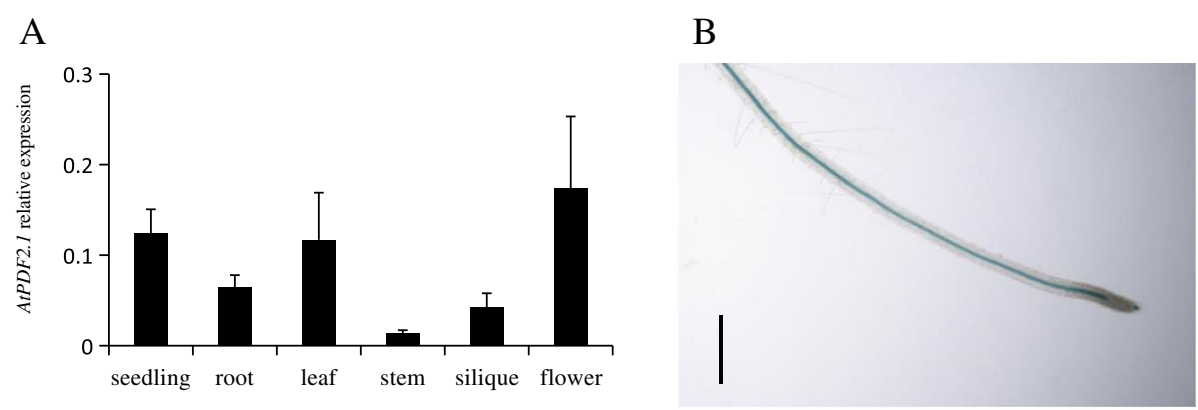

$\mathrm{C}$

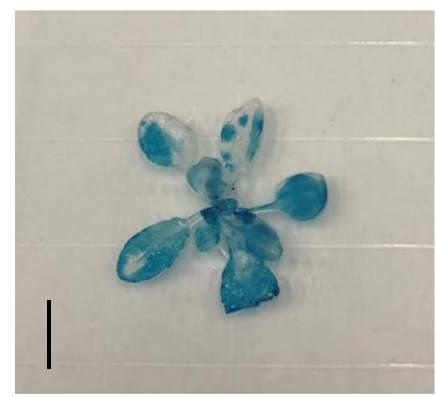

$\mathrm{D}$

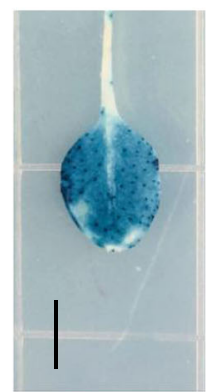

$\mathrm{E}$

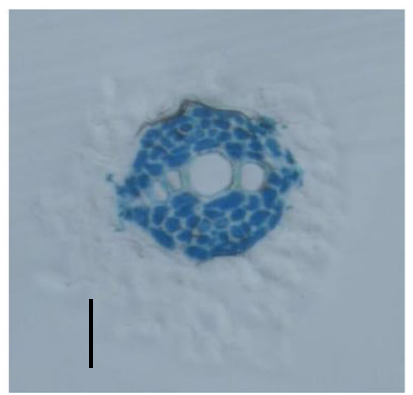

Fig. 3 Expression patterns of AtPDF2.1. AtPDF2.1 is mainly expressed in shoot and root vascular bundles. a Analysis of the relative expression level of AtPDF2.1 in different organs of $A$. thaliana by quantitative real-time PCR. Tissues were harvested either from 45-d-old plants grown in hydroponics (leaves, stems, siliques, and flowers) or from 7-d-old plants grown in 1/2 MS medium (seedlings). Actin2 was used as an internal control. Data are mean $\pm S D, n=4$. $\mathbf{b}$-e Histochemical localization of GUS activity in transgenic plants expressing the GUS reporter gene under the control of the proAtPDF2.1 promoter. b One-week-old whole-mount seedling root. c, d 45-d-old plants shoot (c) and leaves (d). e Crosssection of one-week-old root. Bars $=4 \mathrm{~mm}$ in (b), $2 \mathrm{~cm}$ in (c), $1 \mathrm{~cm}$ in (d), and $10 \mu \mathrm{m}$ in (e) 


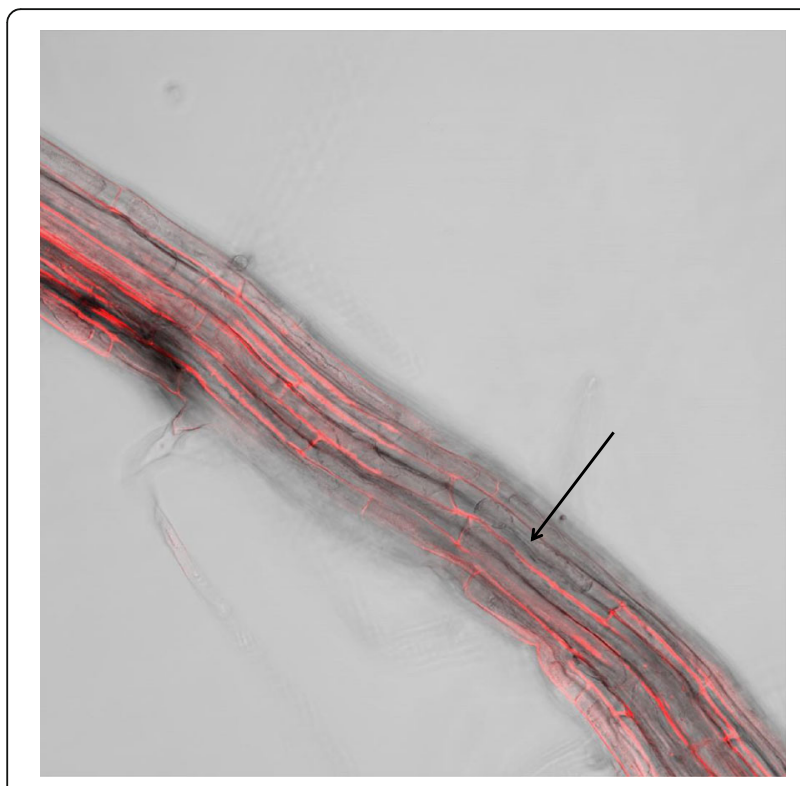

Fig. 4 Confocal observation of red fluorescence in 35S::AtPDF2.1MRFP transgenic A. thaliana. Subcellular localization merge map. Surface sterile seeds were plated onto 1/2 Murashige and Skoog medium and grown vertically for 2 weeks. The root epidermal cells were incubated in $40 \%$ sucrose to induce plasmolysis, and then imaged by confocal microscopy. The arrow points to the plasmic wall separation
Recent studies revealed that CEP family peptides are part of the systemic $\mathrm{N}$-demand signal transduction in roots. They sense signals through their receptor CEPRs, thereby mediating the systemic up-regulation of nitrate transporter genes in roots [13]. However, whether PDFs play a regulatory role in nutrient uptake, transport, or assimilation has not been reported. In the present study, the wild type Col-0 was treated with low nitrate, high nitrate, and ammonium, and the expression of AtPDF family genes under these conditions was analyzed. We found that most $P D F 1$ s responded to nitrate, while PDF2.1 and PDF2.3 were induced by ammonium, especially PDF2.1 (Fig. 1). It has been reported that PDF2.1 and PDF2.3 have high homology [2], and we found that PDF2.1 and PDF2.3 are similarly induced by ammonium, suggesting they might have some functional redundancy, which would explain why phenotypic differences were not obvious between wildtype and PDF2.1 mutants. Recently, we obtained homozygous mutants of PDF2.3 through the clustered regularly interspaced short palindromic repeats (CRISPR)/CRISPR-associated protein 9 technology, and we aim to carry out a series of tests on pdf2.3 single or $p d f 2.1 / p d f 2.3$ double mutants and combine those results with previous ones to gain insight on the functioning of PDF2.1 and PDF2.3. In the present study, PDF2.1 was induced under pure ammonium

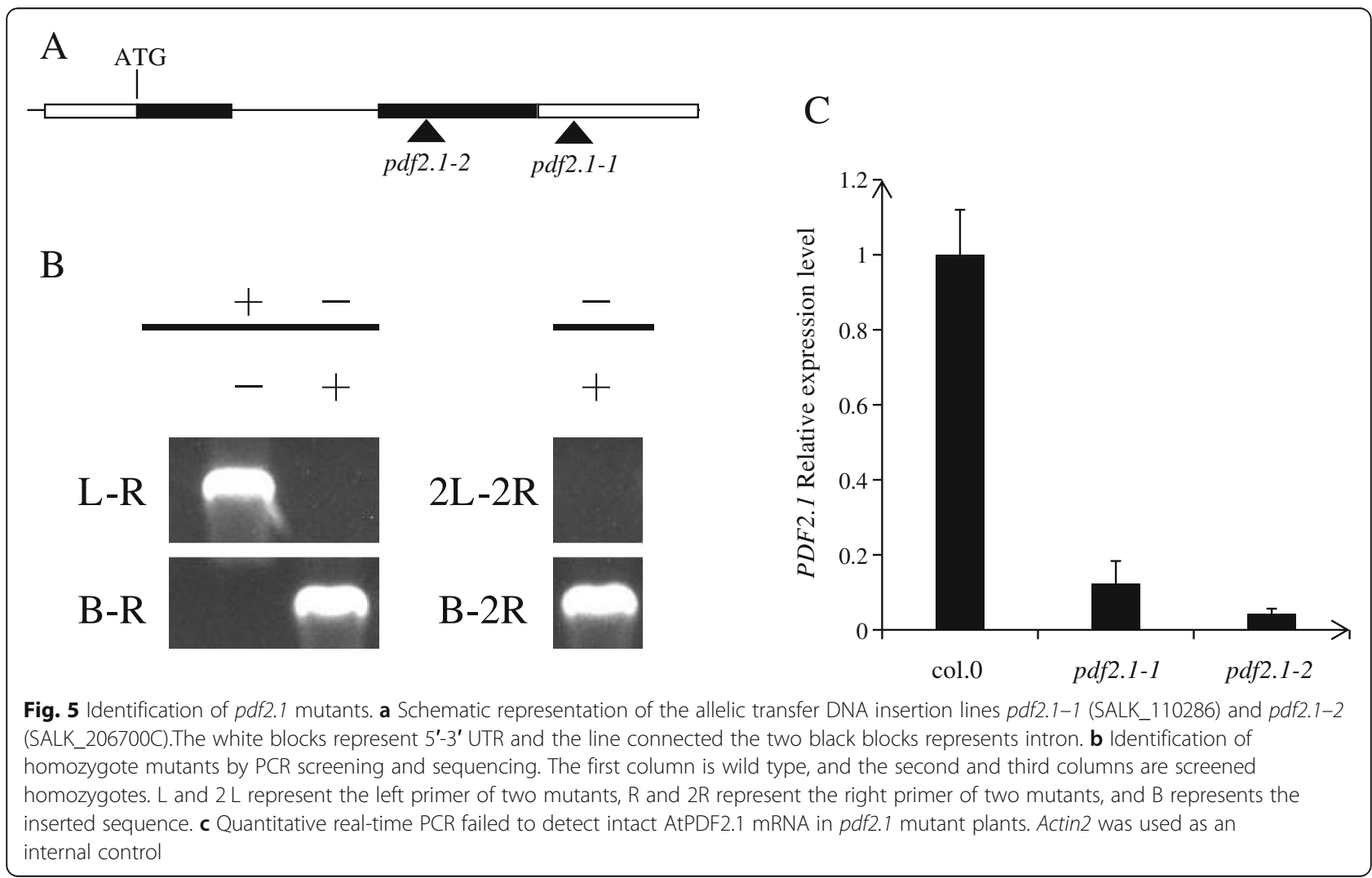




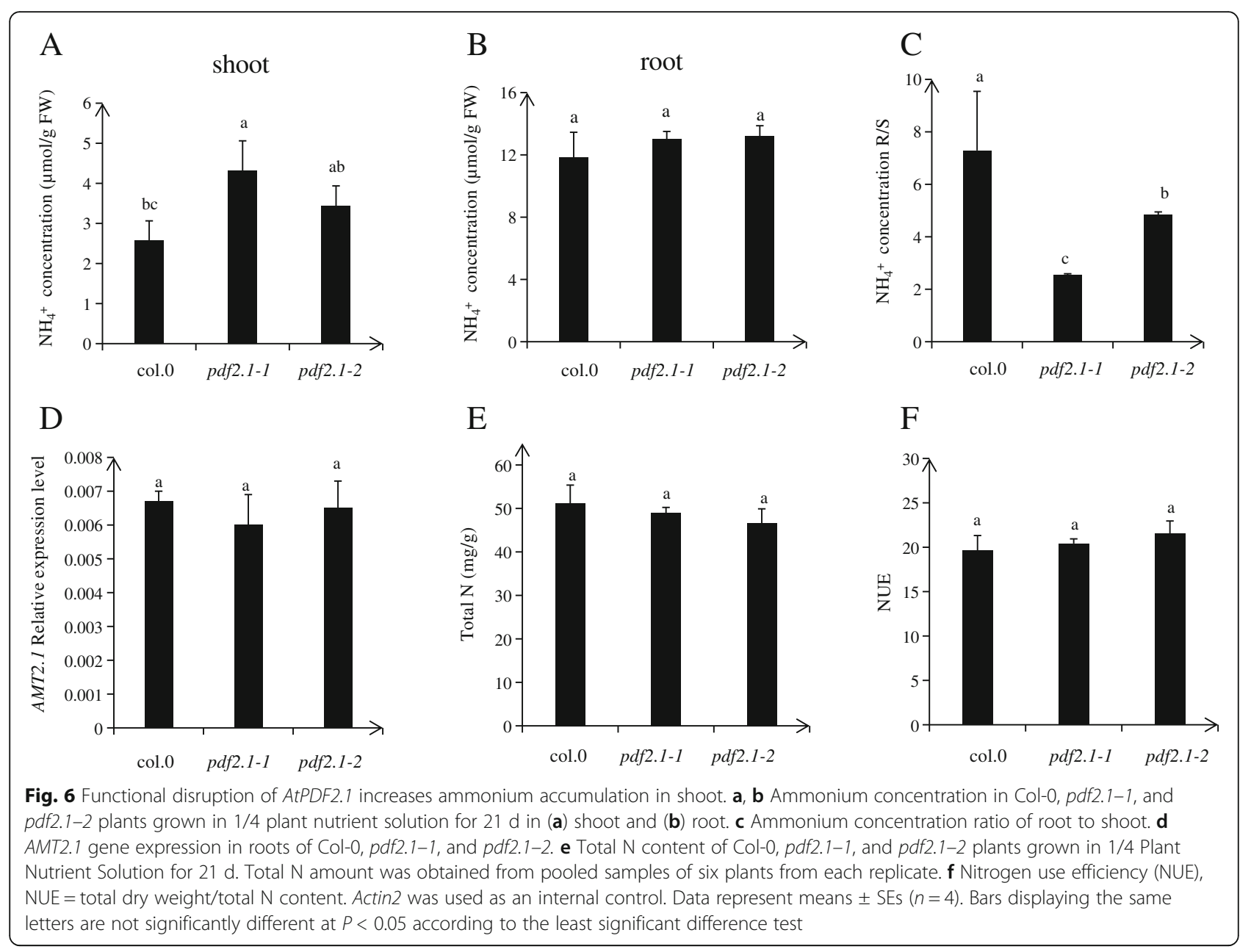

culture conditions (Fig. 2). PDFs are expressed in the xylem, stomata and stomatal cells, parenchyma cells, and other peripheral regions $[1,49]$. Our results also confirmed that AtPDF2.1 is a cell wall protein of $A$. thali$a n a$, which is expressed in all tissues. However, because we did not know how AtPDF2.1 regulates $\mathrm{N}$ and/or ammonium metabolism in $A$. thaliana, we examined Col-0 and PDF2.1 mutant responses of AtPDF2.1 under normal culture conditions.

Firstly, we determined the concentration of ammonium in Col-0, $p d f 2.1-1$, and $p d f 2.1-2$. We found no significant differences in roots between Col- 0 and the mutants, but ammonium concentration was significantly higher in the shoots of mutants than in the shoots of Col-0. However, no significant differences were detected in the expression of AtAMT2.1 between Col-0 and mutants (Fig. 6), indicating that AtPDF2.1 did not affect ammonium transport from roots to shoots. However, no significant differences were observed in shoot and root nitrate concentrations between Col-0 and $p d f 2.1$ mutants (Additional file 1: Figure S1), and there were no differences in the total
$\mathrm{N}$ content and NUE (Fig. 6). Therefore, AtPDF2.1 might affect ammonium metabolism in shoots. The GS enzyme located in the chloroplast and cytoplasm is responsible for assimilating ammonium, which is produced via nitrate reduction $[9,47,48]$.

We measured the activities of enzymes related to $\mathrm{N}$ metabolism in shoots and found that there were no significant differences in NR activities in shoots, while GS activities were significantly lower in $p d f 2.1-1$ and pdf2.1-2 than in Col-0. This suggested that AtPDF2.1 may regulate the further metabolism of ammonium by regulating GS activities. The pdf2.1 mutants showed no effect of most GLN family genes but displayed regulatory effects for GLN1.3 and GLN1.5. In addition, the relative expression of GLN1.5 was low. This might explain why the phenotype was not obvious. A recent study indicated that GLN1.1, GLN1.2, GLN1.3, and GLN1.4 are functional members of the GLN1 gene family in A. thaliana and that they play a synergistic or complementary role in primary $\mathrm{N}$ assimilation, plant growth, seed germination and production, and pollen development [50]. In addition, the major isoforms of $A$. thaliana expressed in 

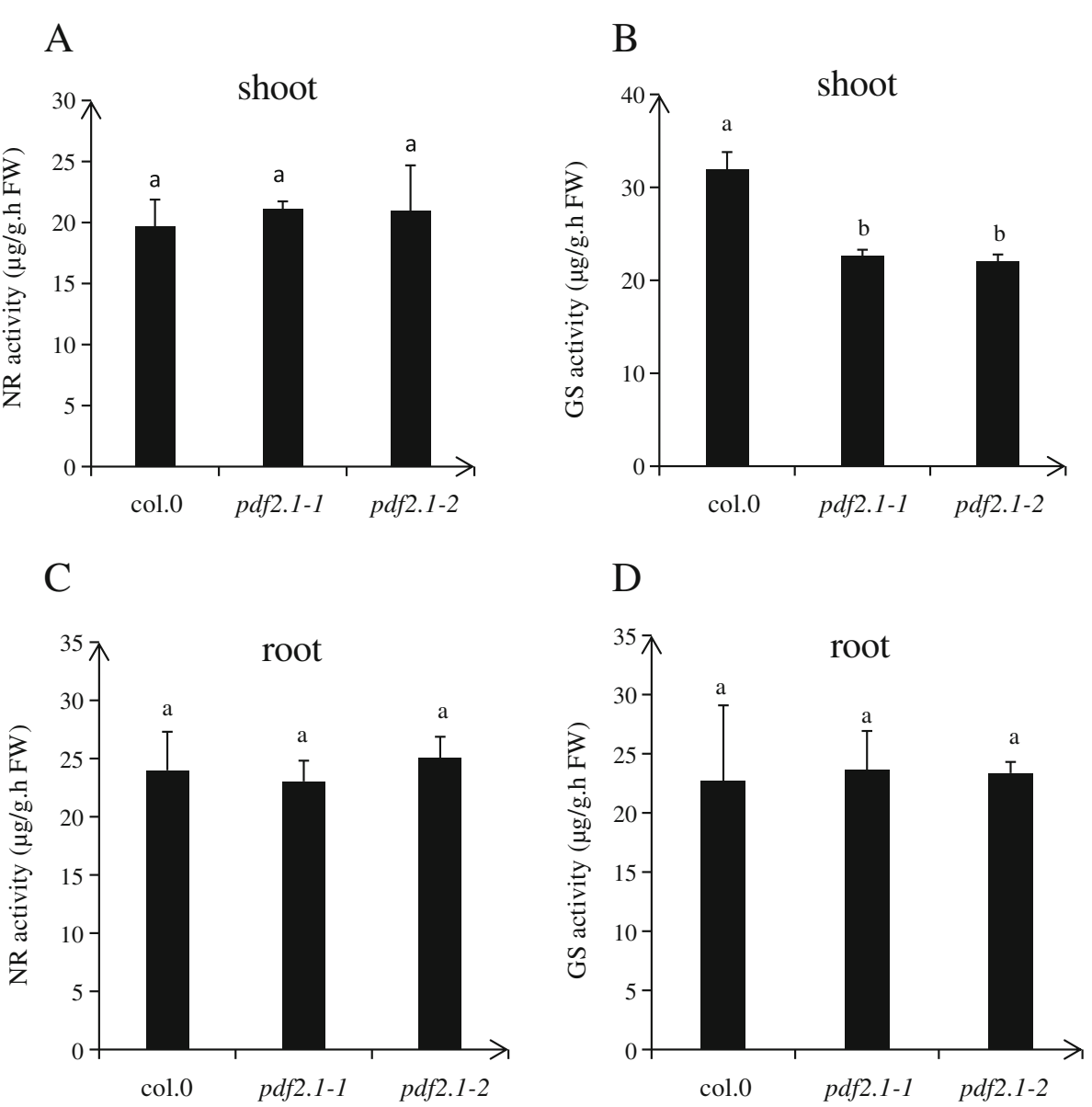

Fig. 7 Functional disruption of AtPDF2.1 decrease GS activity in shoot. Plants were grown in 1/4 plant nutrient solution for $21 \mathrm{~d}$. a NR and (b) GS activities in the shoots of Col-0, pdf2.1-1, and pdf2.1-2, c NR and (d) GS activities in the roots of Col-0, pdf2.1-1, and pdf2.1-2. Data represent means \pm SEs $(n=4)$. Bars displaying the same letters are not significantly different at $P<0.05$ according to the least significant difference test

the seedling stage are GLN1.1, GLN1.2, and GLN1.3 [43]. Other studies have reported that GLN1.2 plays a significant role in seed yield, lotus rosette biomass, and germination $[28,30]$, and that the loss of GLN1.1 and GLN1.3 function reduced the germination rate of plants [50]. This might be why PDF2.1 mutants only partially affected ammonium metabolism.

In this experiment, the concentration of glutamine was higher in mutants than in the wild type, likely due to the decrease of NADH-GOGAT activity in the mutants. However, the expression of glutamate transporter 1 (GLT1), the gene regulating NADH-GOGAT, showed no difference between wild type and mutants (Additional file 1: Figure S2). Thus, this regulation might not occur at the transcriptional level. The decrease of GS activities affected the subsequent metabolic process. However, the glutamate and free amino acid concentrations did not differ significantly between Col-0 and mutants. This might be due to functional redundancy between GLN1.3 and GLN1.1 [50], low expression of GLN1.5, or GLN1.2 playing a leading role among GLN1.1, GLN1.2, and GLN1.3 [51].

Overall, PDF2.1, a cell wall protein, affects ammonium metabolism by regulating the nuclear gene GLN1.3. Several studies revealed that small peptides can be used as signal molecules of protein kinase pathways to indirectly regulate the expression of other genes [13, 14, 52]. For example, the small peptide CLE25 can regulate the expression of NCED3 in the leaves through the receptor kinase BAM, and thus transmits the signal of water shortage, affecting abscisic acid biosynthesis and transpiration and regulating stomata [14]. It has also been suggested that the CEP family peptides are a part of Nsignaling in the root system. They sense signals through two LRR markers, namely CEPR1 and CEPR2, to adjust the systemic upregulation of nitrate transporter genes in the roots [13]. It has been shown that root-derived CEP induces the phloem-specific polypeptides CEPD1 and CEPD2 in the leaves and activates NRT2.1 expression, especially during nitrate uptake by the roots [52]. 


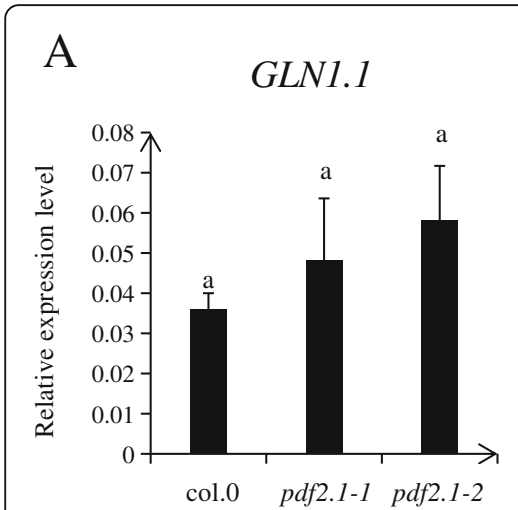

$\mathrm{D}$

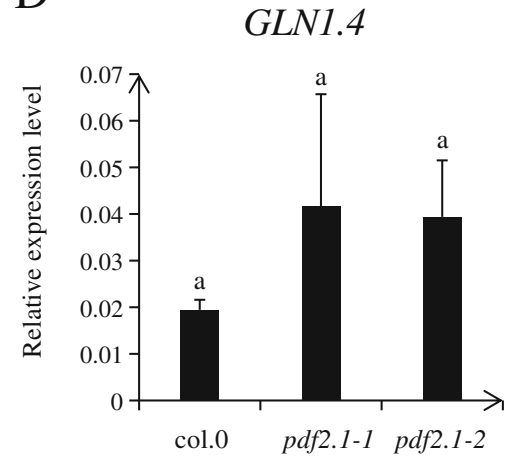

B

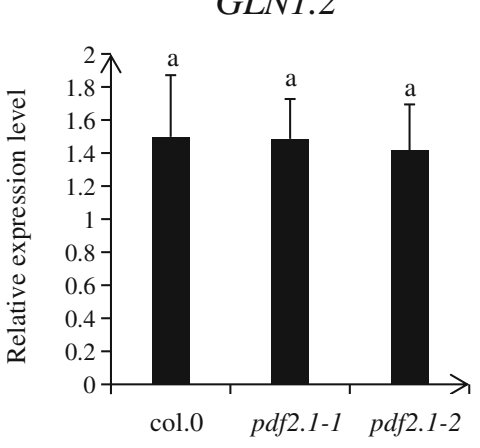

$\mathrm{E}$

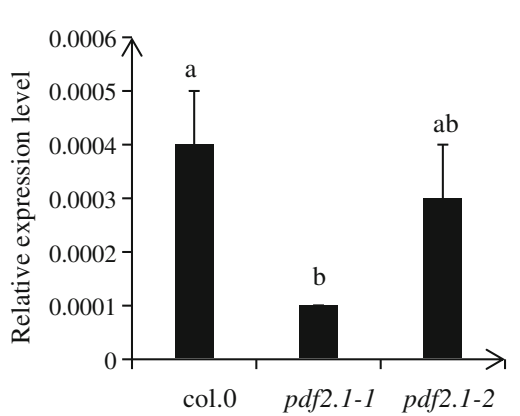

$\mathrm{C}$

GLN1.3

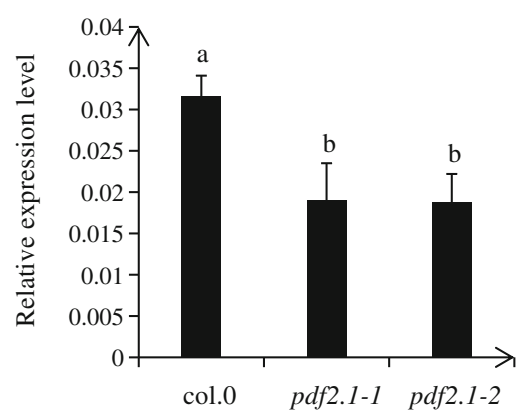

$\mathrm{F}$

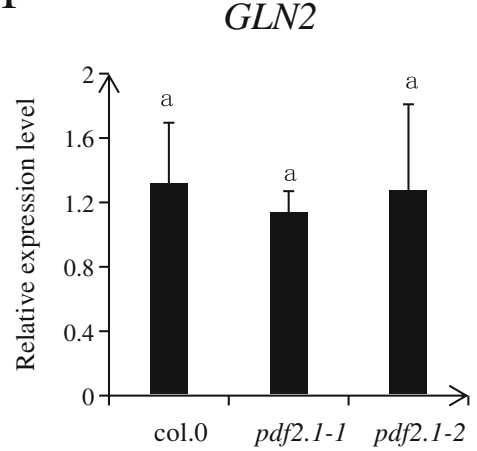

Fig. 8 GLN1.3 and GLN1.5 are down regulated in shoots of pdf2.1 mutant. Plants grown in 1/4 plant nutrient solution for 21 d. Shoots were sampled to examine the expression levels of (a) GLN1.1, b GLN1.2, c GLN1.3, d GLN1.4, e GLN1.5, and f GLN2. Data represent means \pm SEs $(n=4)$. Actin2 was used as an internal control. Bars displaying the same letters are not significantly different at $P<0.05$ according to the least significant difference test

Therefore, we hypothesize that PDF2.1 can also regulate GLN1.3 and AMT2.1 through a protein kinase or downstream transcription factor, thus affecting ammonium metabolism, but the specific process has not been determined.

Based on these results, we believe that AtPDF2.1 regulates the metabolism of ammonium by regulating the activities of GS in the shoot, thereby affecting the concentration of glutamine and the activity of NADHGOGAT.

\section{Conclusions}

Our results showed that PDF2.1 is a cell wall protein in various organs, and that it affects the metabolism of ammonium by regulating the expression of GLN1.3 in plant shoots.

\section{Methods}

\section{Experimental materials and growth conditions}

The A thaliana wild type (Col-0) used as the control group in all experiments was provided by Jiming Gong from Shanghai Institute of Plant Physiology and Ecology. The AtPDF2.1 knockout mutants (pdf2.1-1 and pdf2.1-
2) were obtained from The Arabidopsis Information Resource (TAIR; http://www.arabidopsis.org/). The seeds of Col-0 and AtPDF2.1 knockout mutants were germinated and grown in a greenhouse $(300 \mu \mathrm{mol}$ photons $\mathrm{m}^{-2} \mathrm{~s}^{-1}, 16 \mathrm{~h}$ photoperiod, $22^{\circ} \mathrm{C}$ ) for $10 \mathrm{~d}$. A pair of real leaf seedlings was transplanted into a $4.5-\mathrm{L}$ pot and cultured for 21 days in $1 / 4$ plant nutrient solution containing $1.25 \mathrm{mM} \mathrm{KNO}_{3}, 0.625 \mathrm{mM} \mathrm{KH_{2 }} \mathrm{PO}_{4}, 1.25 \mu \mathrm{M}$ FeEDTA, $0.5 \mathrm{mM} \mathrm{MgSO}_{4}, 0.5 \mathrm{mM} \mathrm{Ca}\left(\mathrm{NO}_{3}\right)_{2}, 0.05 \mu \mathrm{M}$ $\mathrm{NaMoO}_{4}, \quad 0.125 \mu \mathrm{M} \quad \mathrm{CuSO}_{4} \quad 0.25 \mu \mathrm{M} \quad \mathrm{ZnSO}_{4}, \quad 3.5 \mu \mathrm{M}$ $\mathrm{MnCl}_{2}$, and $17.5 \mu \mathrm{M} \mathrm{H}_{3} \mathrm{BO}_{3}$. The $\mathrm{pH}$ of the medium was adjusted to 5.8 , and MES $(2.5 \mathrm{~mm})$ was added to the buffer to adjust any possible change in $\mathrm{pH}$. The medium was renewed every $4 \mathrm{~d}$. Forty-eight plants were planted in each basin, and the growth conditions of all basins were the same.

In the ammonium induction experiments, set to analyze the relative expression levels of AtPDF2.1 under different treatments, Col-0 seedlings were treated with $1 / 4$ plant nutrient solution for $18 \mathrm{~d}$ and then subject to $\mathrm{N}$ starvation for $3 \mathrm{~d}$. After this period, seedlings were treated with $2.25 \mathrm{mM} \mathrm{KNO} 3,1.125 \mathrm{mM}\left(\mathrm{NH}_{4}\right)_{2} \mathrm{SO}_{4}$, or $1.125 \mathrm{mM} \mathrm{K}_{2} \mathrm{SO}_{4}$ for $6 \mathrm{~h}$, before roots and shoots were 

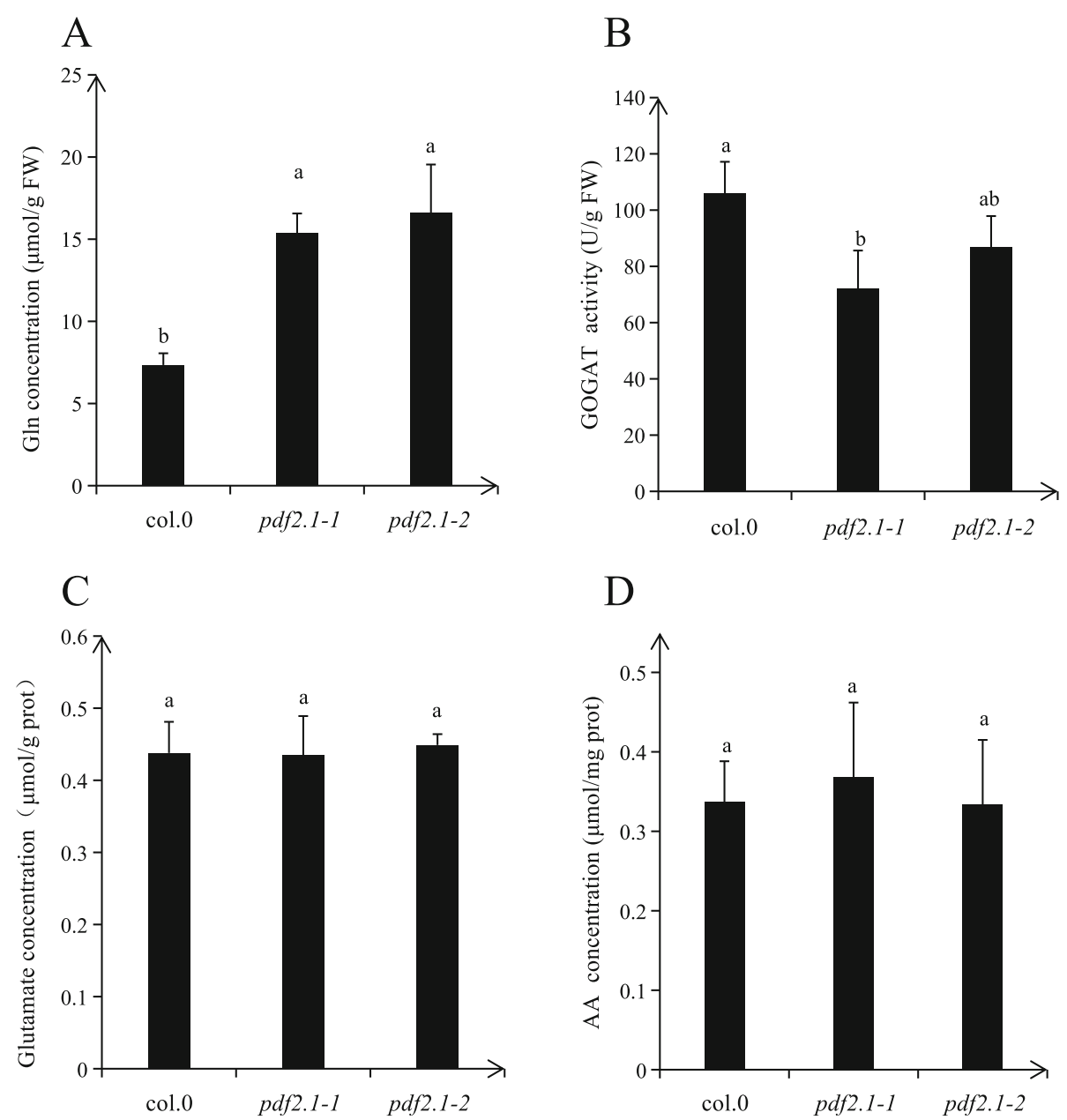

Fig. 9 Activities of ammonium assimilation enzymes and concentration of ammonium assimilation products in shoots of Col-0 and pdf2.1 mutants. Plants were grown in 1/4 plant nutrient solution for $21 \mathrm{~d}$. a Concentration of glutamine (Gln). b Activity of glutamate synthase (NADHGOGAT). c Concentration of glutamate (Glu). $\mathbf{d}$ Concentration of total amino acids (AA) in shoots of Col-0, pdf2.1-1, and pdf2.1-2. Data represent means \pm SEs $(n=4)$. Bars displaying the same letters are not significantly different at $P<0.05$ according to the least significant difference test

harvested separately for RNA extraction and AtPDF2.1 expression analysis.

In other experiments, Col- 0 , pdf2.1-1, and $p d f 2.1-2$ seedlings were treated with $1 / 4$ plant nutrient solution for $21 \mathrm{~d}$ and then sampled and analyzed.

\section{Histochemical analysis}

The 1805-bp genomic fragment immediately upstream of the initial codon of AtPDF2.1 was amplified by PCR using primer ProAtPDF2.1 (Additional file 1: Table S1). Then, subcloning the generated ProAtPDF2.1 promoter split into binary vector pCAMBIA1300 [53]. The $A$. thaliana seedlings cultured in water for $21 \mathrm{~d}$ were sampled as reported in section "Experimental materials and growth conditions". Semi-thin sections $(4 \mu \mathrm{m})$ were cut from the root, fixed on slides, and observed under the Leica-DM6000 microscope. Histochemical staining driven by the ProAtPDF2.1 promoter was performed using the GUS histochemical analysis kit (Real-Times). The staining pattern of GUS in the root was observed under the Olympus BX51 microscope and photographed using the Fujifilm X-A3 camera.

\section{DNA constructs and transformation into plants}

The coding sequence of AtPDF2.1 was amplified by PCR using primers AtPDF2.1F and AtPDF2.1R (Additional file 1: Table S1), and then the subcellular location of AtPDF2.1 in Arabidopsis was determined. Subcloning was performed to generate construct 35S::mRFP/1300. The resulting fragment was framed with the 5 'end of the single red fluorescent protein (mRFP) gene to produce the 35S::AtPDF2.1-mRFP/pCAMBIA1300 constructs. These constructs were modified by replacing the $35 \mathrm{~S}$ promoter with the native promoter proAtPDF2.1, resulting in the proAtPDF2.1::AtPDF2.1-mRFP/pCAMBIA1300 constructs, which were transformed into $A$. 
thaliana using the floral dip method [54]. The root tissue of transgenic plants was then imaged by mRFP using a confocal microscope (LSM880; Zeiss).

\section{Quantification of N concentrations}

Using hydroponics, after $21 \mathrm{~d}$, the shoots and roots of Col-0 and mutant $A$. thaliana plants were individually sampled, frozen in liquid $\mathrm{N}$, and stored at $-80^{\circ} \mathrm{C}$ until further analysis. Indophenol blue colorimetry, at $630 \mathrm{~nm}$ [55-57] and using $\left(\mathrm{NH}_{4}\right)_{2} \mathrm{SO}_{4}$, was performed to measure ammonium concentration. Nitrate concentration in the roots and leaves was determined at $410 \mathrm{~nm}$ [57-59] spectrophotometrically. Total $\mathrm{N}$ concentration was determined as described by Wang et al. [60]. In the present study, NUE was determined as total biomass/total $\mathrm{N}$ accumulation [61].

\section{Nitrogen and ammonium metabolism-related enzyme activities}

$\mathrm{N}$ metabolism in plants is closely associated with the activities of several key enzymes, such as NR and GS [62]. For NR activity determination, the roots and leaves harvested were frozen in liquid $\mathrm{N}$ immediately, and then stored at $-80^{\circ} \mathrm{C}$ until further analysis. Samples were ground to a fine powder ( $100 \mathrm{mg})$, extracted, and analyzed spectrophotometrically [57, 63, 64]. The activity of GS was assayed as reported by Wang et al. [65]. The activity of NADH-GOGAT was quantified using a NADHGOGAT measurement kit (Solarbio Bioengineering Institute). Glutamate and glutamine were quantified using a glutamic acid measurement kit and a glutamine measurement kit, respectively (both from Nanjing Jiancheng Bioengineering Institute). Enzyme activities were expressed as moles of metabolite generated/consumed per milligram of fresh weight or protein per unit of time. The protein concentration was determined by the Coomassie brilliant blue method with Modified BCA Protein Assay Kit, C503051, Sangon Biotech.

\section{Amino acids quantification}

High-performance liquid chromatography (HPLC) was used to quantify amino acids in the shoots as reported by Del Campo et al. [66]. Frozen leaf samples $(200 \mathrm{mg})$ were pulverized with liquid $\mathrm{N}$ and homogenized in $1.5 \mathrm{~mL}$ of $0.1 \%$ phenol and $6 \mathrm{M} \mathrm{HCl}$. The homogenate was hydrolyzed for $22 \mathrm{~h}$ at $100^{\circ} \mathrm{C}$, and then cooled. One milliliter of the hydrolysate was dried using NDK200-2 organomation (Hangzhou MIU Instrument Co., Ltd.) and re-dissolved in $1 \mathrm{~mL}$ of $0.1 \mathrm{M} \mathrm{HCl}$. To quantify the amino acids, $200 \mu \mathrm{L}$ of the re-dissolved hydrolysate was mixed with $20 \mu \mathrm{L}$ of norleucine internal standard solution, $200 \mu \mathrm{L}$ of triethylamine acetonitrile $(\mathrm{pH}>7)$, and $100 \mu \mathrm{L}$ of isothiocyanate acetonitrile, and the mixture was incubated at $25^{\circ} \mathrm{C}$ for 1 h. After adding $400 \mu \mathrm{L}$ of hexane, the sample was incubated for another $10 \mathrm{~min}$ with shaking. The solution in the underlay was passed through a $0.45-\mu \mathrm{m}$ syringe filter. All HPLC analyses were performed on the RIGOL L3000 system (Beijing RIGOL Technology Co., Ltd.). Chromatographic separation was accomplished using an RP-HPLC ACE column (5C18-HL) with a particle size of $5 \mu \mathrm{m}(250 \mathrm{~mm} \times 4.6 \mathrm{~mm})$, at $100^{\circ} \mathrm{C}$ through a binary gradient. Mobile phase A was $25 \mathrm{mM}$ acetate buffer (pH 6.5) and $70 \mathrm{~mL}$ acetonitrile. Mobile phase B was $80 \%$ acetonitrile aqueous solution. The flow rate was $1.0 \mathrm{~mL} \mathrm{~min}^{-1}$ and the column temperature was $40^{\circ} \mathrm{C}$.

\section{Genotyping, RNA extraction, and quantitative PCR}

To identify the mutants, the total DNA was extracted from 21-d-old plants grown in $1 / 2$ plant nutrient solution (leaves), which were used as templates in the PCR with the primers presented in Additional file 1: Table S1.

In the ammonium induction experiments, the roots and shoots of Col- 0 seedlings, which were treated with $1 / 4$ plant nutrient solution for $18 \mathrm{~d}$, and then $\mathrm{N}$-starved for $3 \mathrm{~d}$ before treatment, were separately harvested, frozen in liquid $\mathrm{N}$, and stored at $-80^{\circ} \mathrm{C}$ until RNA analysis. To analyze the expression pattern of PDF2.1, tissues were harvested from 45-d-old plants grown in hydroponics (leaves, stems, siliques, and flowers) or from 7 -d-old plants grown in $1 / 2$ plant nutrient solution (seedlings). The total RNA was extracted with TRIzol (Invitrogen), precipitated with an equal volume of isopropanol, washed with $75 \%$ ethanol, and dissolved in RNase-free water, according to the manufacturer's instructions. Complementary DNA was synthesized using the PrimeScript ${ }^{\text {max }}$ RT Kit with gDNA Eraser (Perfect Real Time; TAKARA) following the protocol of the manufacturer. The relative expression of the target genes was determined by quantitative real-time PCR performed on an Applied Biosystems StepOne ${ }^{\text {Tw }}$ Real-Time PCR System with SYBR Premix Ex-Taq (TAKARA), according to the manufacturer's instructions. The relative expression of the target genes was normalized to that of the reference gene using the $2^{-\Delta \Delta C T}$ method [67]. Primers used in the assays are listed in Additional file 1: Table S1, and the expression data were normalized to that of Actin2, which was used as the internal standard.

\section{Statistical analyses}

In this study, all experiments were in progress using a completely randomized design. Four biological replicates and two technical replicates were applied for each treatment. The least significant difference multiple range test was used to perform multiple comparisons. Differences between the wild type and mutants were evaluated using Student's $t$-test with Statistical Productions and Service Solutions 17.0 (SPSS, Chicago, IL, USA). These Differences were considered statistically significant at $P<0.05$. 


\section{Supplementary information}

Supplementary information accompanies this paper at https://doi.org/10. 1186/s12870-019-2183-2

Additional file 1: Figure S1. Nitrate concentration in A. thaliana, Figure S2. Relative expression level of AtGLT1 in the shoots of of Col-0, pdf2.1-1, and pdf2.1-2 A. thaliana plants grown in 1/4 plant nutrient solution for $21 \mathrm{~d}$, Table S1. Primers used in the present study

\section{Abbreviations}

AMT: Ammonium transporters; GDH: Glutamate dehydrogenase; GOGAT: Glutamine oxoglutarate transaminase; GS: Glutamine synthetase; N: Nitrogen; NR: Nitrate reductase; NUE: Nitrogen use efficiency; PDF: Plant defensins

\section{Acknowledgments}

We thank Can Peng (Core Facility, The Institute of Subtropical Agriculture, The Chinese Academy of Sciences) for help with confocal microscopy.

\section{Authors' contributions}

J-YY, J-SL and Z-HZ designed the experiments; J-YY performed most of the experiments; $Y X$ performed part of the experiments; J-YY and Z-HZ analyzed the data; and J-YY and Z-HZ wrote the manuscript. All authors agree with the manuscript contents and with its submission. All authors read and approved the final manuscrip

\section{Funding}

This study was partly supported by the National Key R\&D Program of China (2017YFD0200100; 2017YFD0200103); National Natural Science Foundation of China (31800202); Province Key R\&D Program of Hunan (2018NK1010); China Postdoctoral Science Foundation (2018 M630900); Hunan Provincial Recruitment Program of Foreign Experts; the National Oilseed Rape Production Technology System of China; "2011 Plan" supported by The Chinese Ministry of Education; and Double First-Class Construction Project of Hunan Agricultural University (kxk201801005), and the Innovative Research Groups of the Natural Science Foundation of Hunan Province (2019JJ10003). The funding bodies were not involved in the design of the study, collection, analysis, and interpretation of data, and in writing the manuscript.

\section{Availability of data and materials}

The datasets used and/or analyzed during the current study are available from the corresponding author on reasonable request.

\section{Ethics approval and consent to participate}

Not applicable.

\section{Consent for publication}

Not applicable.

\section{Competing interests}

The authors declare that they have no competing interests.

\section{Author details}

${ }^{1}$ Southern Regional Collaborative Innovation Center for Grain and Oil Crops in China, College of Resources and Environmental Sciences, Hunan Agricultural University, Changsha, China. ${ }^{2}$ Hunan Provincial Key Laboratory of Farmland Pollution Control and Agricultural Resources Use, Hunan Provincial Key Laboratory of Nutrition in Common University, National Engineering Laboratory on Soil and Fertilizer Resources Efficient Utilization, Changsha 410128, China.

Received: 2 August 2019 Accepted: 3 December 2019 Published online: 16 December 2019

\section{References}

1. García-Olmedo F, Molina A, Alamillo JM, Rodríguez-Palenzuéla P. Plant defense peptides. Biopolymers. 1998;47:479-91.

2. Thomma BP, Cammue BP, Thevissen K. Plant defensins. Planta. 2002;216: 193-202.
3. Fant F, Vranken W, Broekaert W, Borremans F. Determination of the threedimensional solution structure of Raphanus sativus antifungal protein 1 by 1H NMR. J Mol Biol. 1998;279:257-70

4. Ganz T. Defensins: antimicrobial peptides of innate immunity. Nat Rev Immunol. 2003;3:710-20.

5. Thevissen $\mathrm{K}$, Warnecke DC, François IEJA, Leipelt M, Heiz E, Ott C, Zähringer U, Thomma BP, Ferket KK, Cammue BP. Defensins from insects and plants interact with fungal glucosylceramides. J Biol Chem. 2004;279:3900-5.

6. Penninckx IA, Eggermont K, Terras FR, Thomma BP, De Samblanx GW, Buchala A. Pathogen-induced systemic activation of a plant defensin gene in Arabidopsis follows a salicylic acid-independent pathway. Plant Cell. 1996;8:2309-23.

7. Koike M, Okamoto T, Tsuda S, Imai R. A novel plant defensin-like gene of winter wheat is specifically induced during cold acclimation. Biochem Bioph Res Co. 2002;298:46-53.

8. Do HM, Lee SC, Jung HW, Sohn KH, Hwang BK. Differential expression and in situ localization of a pepper defensin (CADEF1) gene in response to pathogen infection, abiotic elicitors and environmental stresses in Capsicum annuum. Plant Sci. 2004;166:1297-305.

9. Mirouze M, Sels J, Richard O, Czrnic P, Loubet S, Jacqyuier A, François IE, Cammue BP, Lebrun M, Berthomieu P, Marquès L. A putative novel role for plant defensins: a defensin from the zinc hyper-accumulating plant, Arabidopsis halleri, confers zinc tolerance. Plant J. 2006;47:329-42.

10. Vriens K, Peigneur S, De Coninck B, Tytgat J, Cammue BP, Thevissen K. The antifungal plant defensin AtPDF2. 3 from $A$. thaliana blocks potassium channels. Sci Rep. 2016;6:32121.

11. Luo JS, Huang J, Zeng DL, Peng JS, Zhang GB, Ma HL, Guan Y, Yi HY, Fu YL, Han B, Lin HX, Qian Q, Gong JM. A defensin-like protein drives cadmium efflux and allocation in rice. Nat Commun. 2018;9:645.

12. Luo JS, Yang Y, Gu TY, Wu ZM, Zhang ZH. The Arabidopsis defensin gene AtPDF2. 5 mediates cadmium tolerance and accumulation. Plant Cell Environ. 2019:1-15. https://doi.org/10.1111/pce.13592.

13. Tabata $R$, Sumida $K$, Yoshii T, Ohyama K, Shinohara H, Matsubayashi $Y$. Perception of root-derived peptides by shoot LRR-RKs mediates systemic Ndemand signaling. Science, 2014:346:343-6.

14. Takahashi F, Suzuki T, Osakabe Y, Betsuyaku S, Kondo Y, Dohmae N, Fukuda H, Yamaguchi-Shinozaki K, Shinozaki K. A small peptide modulates stomatal control via abscisic acid in long-distance signalling. Nature. 2018;556:235-8.

15. Delay C, Imin N, Djordjevic MA. CEP genes regulate root and shoot development in response to environmental cues and are specific to seed plants. J Exp Bot. 2013:64:5383-94.

16. Soyano T, Hirakawa H, Sato S, Hayashi M, Kawaguchi M. NODULE INCEPTION creates a long-distance negative feedback loop involved in homeostatic regulation of nodule organ production. P Natl Acad Sci USA. 2014;111:14607-12.

17. Hu B, Jiang ZM, Wang W, Qiu YH, Zhang ZH, Liu YQ, Li AF, Gao XK, Liu LH, Qian YW, Huang XH, Yu FF, Kang S, Wang YQ, Xie JP, Cao SY, Zhang LH, Wang YC, Xie Q, Kopriva S, Chu CC. Nitrate-NRT1.1B-SPX4 cascade integrates nitrogen and phosphorus signalling networks in plants. Nat Plants. 2019;5:401-13.

18. Crawford NM. Nitrate: nutrient and signal for plant growth. Plant Cell. 1995;7:859-68

19. Barlóg P, Grzebisz W. Effect of timing and nitrogen fertilizer application on winter oilseed rape (Brassica napus L.). II. Nitrogen uptake dynamics and fertilizer efficiency. J Agron Crop Sci. 2004;190:314-23.

20. Grant CA, Wu R, Selles F, Harker KN, Clayton GW, Bittman S, Zebarth BJ, Lupwayi NZ. Crop yield and nitrogen concentration with controlled release urea and split applications of nitrogen as compared to non-coated urea applied at seeding. Field Crop Res. 2012;127:170-80.

21. MacKintosh C, Meek SEM. Regulation of plant NR activity by reversible phosphorylation, 14-3-3 proteins and proteolysis. Cell Mol Life Sci. 2001;58:205-14.

22. Hoff T, Truong HN, Caboche M. The use of mutants and transgenic plants to study nitrate assimilation. Plant Cell Environ. 1994;17:489-506.

23. Konishi M, Yanagisawa S. Arabidopsis NIN-like transcription factors have a central role in nitrate signalling. Nat Commun. 2013;4:1617-25.

24. Konishi M, Yanagisawa S. Emergence of a new step towards understanding the molecular mechanisms underlying nitrate-regulated gene expression. J Exp Bot. 2014:65:5589-600

25. Lam HM, Coschigano KT, Oliveira IC, Melo-Oliveira R, Coruzzi GM. The molecular-genetics of nitrogen assimilation into amino acids in higher plants. Annu Rev Plant Biol. 1996;47:569-93. 
26. Khademi S, O'Connell J 3rd, Remis J, Robles-Colmenares Y, Miercke LJ, Stroud RM. Mechanism of ammonia transport by Amt/MEP/Rh: structure of AmtB at 1.35 A. Science. 2004;305:1587-94.

27. Ortiz-Ramirez C, Mora SI, Trejo J, Pantoja O. PVAMT1;1, a highly selective ammonium transporter that functions as an $\mathrm{H}^{+} / \mathrm{NH}^{+}$symporter. J Biol Chem. 2011;286:31113-22.

28. Lothier J, Gaufichon L, Sormani R, Lemaître T, Azzopardi M, Morin H, Chardon F, Reisdorf-Cren M, Avice J, Masclaux-Daubresse C. The cytosolic glutamine synthetase GLN1;2 plays a role in the control of plant growth and ammonium homeostasis in Arabidopsis rosettes when nitrate supply is not limiting. J Exp Bot. 2011;62:1375-90.

29. Guan M, Møller IS, Schjørring JK. Two cytosolic glutamine synthetase isoforms play specific roles for seed germination and seed yield structure in Arabidopsis. J Exp Bot. 2014;66:203-12.

30. Guan M, de Bang TC, Pedersen C, Schjoerring JK. Cytosolic glutamine synthetase GIn1; 2 is the main isozyme contributing to GS1 activity and can be up-regulated to relieve ammonium toxicity. Plant Physiol. 2016;171: 1921-33.

31. Ishiyama K, Inoue E, Watanabe-Takahashi A, Obara M, Yamaya T, Takahashi $H$. Kinetic properties and ammonium-dependent regulation of cytosolic isoenzymes of glutamine synthetase in Arabidopsis. J Biol Chem. 2004;279: 16598-605.

32. Konishi N, Saito M, Imagawa F, Kanno K, Yamaya T, Kojima S. Cytosolic glutamine synthetase isozymes play redundant roles in ammonium assimilation under low-ammonium conditions in roots of Arabidopsis thaliana. Plant Cell Physiol. 2018;59:601-13.

33. Martin A, Belastegui-Macadam X, Quilleré I, Floriot M, Valadier MH, Pommel B, Andrieu B, Donnison I, Hirel B. Nitrogen management and senescence in two maize hybrids differing in the persistence of leaf greenness: agronomic, physiological and molecular aspects. New Phytol. 2005;167:483-92.

34. Martin A, Lee J, Kichey T, Gerentes D, Zivy M, Tatout C, Dubois F, Balliau T, Valot B, Davanture M, Tercé-Laforgue T, Quilleré I, Coque M, Gallais A, Gonzalez-Moro M, Bethencourt L, Habash D, Lea P, Charcosset A, Perez P, Murigneux A, Sakakibara H, Edwards K, Hirel B. Two cytosolic glutamine synthetase isoforms of maize are specifically involved in the control of grain production. Plant Cell. 2006;18:3252-74.

35. Dragićević M, Simonović A, Bogdanović M, Subotić A, Ghalawenji N, Dragićević I, Todorović S. Differential regulation of GS-GOGAT gene expression by plant growth regulators in Arabidopsis seedlings. Arch Biol Sci. 2016;68:399-404

36. Taira M, Valtersson U, Burkhardt B, Ludwig RA. Arabidopsis thaliana GLN2encoded glutamine synthetase is dual targeted to leaf mitochondria and chloroplasts. Plant Cell. 2004;16:2048-58.

37. Xu G, Fan X, Miller AJ. Plant nitrogen assimilation and use efficiency. Annu Rev Plant Biol. 2012;63:153-82.

38. Fontaine JX, Tercé-Laforgue T, Armengaud P, Clément G, Renou JP, Pelletier S, Catterou M, Azzopardi M, Gibon Y, Lea PJ, Hirel B, Dubois F. Characterization of a NADH-dependent glutamate dehydrogenase mutant of Arabidopsis demonstrates the key role of this enzyme in root carbon and nitrogen metabolism. Plant Cell. 2012;24:4044-65.

39. Tercé-Laforgue T, Bedu M, Dargel-Grafin C, Dubois F, Gibon Y, Restivo FM, Hirel B. Resolving the role of plant glutamate dehydrogenase: II. Physiological characterization of plants overexpressing the two enzyme subunits individually or simultaneously. Plant Cell Physiol. 2013;54:1635-47.

40. Meyer C, Stitt M. Nitrate reduction and signalling. Plant nitrogen. Berlin: Springer; 2001. p. 37-59.

41. Forde BG. Nitrogen signalling pathways shaping root system architecture: an update. Curr Opin Plant Biol. 2014;21:30-6.

42. Nacry P, Bouguyon E, Gojon A. Nitrogen acquisition by roots: physiological and developmental mechanisms ensuring plant adaptation to a fluctuating resource. Plant Soil. 2013;370:1-29.

43. Sohlenkamp C, Shelden M, Howitt S, Udvardi M. Characterization of Arabidopsis AtAMT2, a novel ammonium transporter in plants. FEBS Lett. 2000;467:273-8.

44. Giehl RFH, Laginha AM, Duan F, Rentsch D, Yuan L, von Wirén N. A critical role of AMT2; 1 in root-to-shoot translocation of ammonium in Arabidopsis. Mol Plant. 2017;10:1449-60.

45. Mendez E, Moreno A, Colilla F, Pelaez F, Limas GG, Mendez R, Soriano F, Salinas $M$, de HARO C. Primary structure and inhibition of protein synthesis in eukaryotic cell-free system of a novel thionin, gamma-hordothionin, from barley. Biochemistry. 1990;194:533-9.
46. De Coninck BM, Sels J, Venmans E, Thys W, Goderis IJ, Carron D, Delauré SL, Cammue BP, De Bolle MF, Mathys J. Arabidopsis thaliana plant defensin AtPDF1. 1 is involved in the plant response to biotic stress. New Phytol. 2010;187:1075-88.

47. Shahzad Z, Ranwez V, Fizames C, Marquès L, Le Martret B, Alassimone J, Godé C, Lacombe E, Castillo T, Saumitou-Laprade P, Berthomieu P, Gosti F. Plant Defensin type 1 (PDF1): protein promiscuity and expression variation within the Arabidopsis genus shed light on zinc tolerance acquisition in Arabidopsis halleri. New Phytol. 2013;200:820-33.

48. Nguyen NN, Ranwez V, Vile D, SOULIE MC, Dellagi A, Expert D, Gosti F. Evolutionary tinkering of the expression of PDF1s suggests their joint effect on zinc tolerance and the response to pathogen attack. Front Plant Sci. 2014;5:70.

49. Kragh KM, Nielsen JE, Nielsen KK, Dreboldt S, Mikkelsen JD. Characterization and localization of new antifungal cysteine-rich proteins from Beta vulgaris. Mol Plant-Microbe Interact. 1995;8:424-34.

50. Ji Y, Li Q, Liu G, Selvaraj G, Zheng Z, Zou J, Wei Y. Roles of cytosolic glutamine Synthetases in Arabidopsis development and stress responses. Plant Cell Physiol. 2019;60:657-71.

51. Konishi N, Ishiyama K, Beier MP, Inoue E, Kanno K, Yamaya T, Takahashi H, Kojima S. Contributions of two cytosolic glutamine synthetase isozymes to ammonium assimilation in Arabidopsis roots. J Exp Bot. 2016;68:613-25.

52. Ohkubo Y, Tanaka M, Tabata R, Ogawa-Ohnishi M, Matsubayashi Y. Shootto-root mobile polypeptides involved in systemic regulation of nitrogen acquisition. Nat Plants. 2017;3:17029.

53. Zhang GB, Yi HY, Gong JM. The Arabidopsis ethylene/jasmonic acid-NRT signaling module coordinates nitrate reallocation and the trade-off between growth and environmental adaptation. Plant Cell. 2014;26:3984-98.

54. Clough SJ, Bent AF. Floral dip: a simplified method for agrobacterium mediated transformation of Arabidopsis thaliana. Plant J. 1998;16:735-43.

55. Cataldo DA, Maroon M, Schrader LE, Youngs VL. Rapid colorimetric determination of nitrate in plant tissue by nitration of salicylic acid. Commun Soil Sci Plan. 1975;6:71-80.

56. Santoni S, Bonifacio E, Zanini E. Indophenol blue colorimetric method for measuring cation exchange capacity in sandy soils. Commun Soil Sci Plant. 2001;32:2519-30.

57. Singh R, Parihar P, Prasad SM. Sulfur and calcium simultaneously regulate photosynthetic performance and nitrogen metabolism status in Aschallenged Brassica juncea L seedlings. Front Plant Sci. 2018;9:772.

58. Molins-Legua C, Meseguer-Lloret S, Moliner-Martinez Y, Campíns-Falcó P. A guide for selecting the most appropriate method for ammonium determination in water analysis. Trac-Trend Anal Chem. 2006;25:282-90.

59. Patterson K, Cakmak T, Cooper A, Lager I, Rasmusson AG, Escober MA. Distinct signalling pathways and transcriptome response signatures differentiate ammonium- and nitrate-supplied plants. Plant Cell Environ. 2010;33:1486-501.

60. Wang RC, Xing XJ, Wang Y, Tran A, Crawford NM. A genetic screen for nitrate regulatory mutants captures the nitrate transporter gene NRT1.1. Plant Physiol. 2009;151:472-8.

61. Li H, Li MC, Luo J, Cao X, Qu L, Gai Y, Jiang XN, Liu TX, Bai H, Janz D, Polle A, Peng $\mathrm{CH}$, Luo ZB. N-fertilization has different effects on the growth, carbon and nitrogen physiology, and wood properties of slow- and fastgrowing Populus species. J Exp Bot. 2012;63:6173-85.

62. Rennenberg $\mathrm{H}$, Wildhagen $\mathrm{H}$, Ehlting $\mathrm{B}$. Nitrogen nutrition of poplar trees. Plant Biol. 2010;12:275-91.

63. Robin P. Etude de quelques conditions d'extraction de la nitrate reductase des racines et des feuilles de plantules de maïs. Physiol Veg. 1979:17:45-54.

64. Ehlting B, Dluzniewska P, Dietrich H, Selle A, Teuber M, Hänsch R, Nehls U, Polle A, Schnitzler JP, Rennenberg H, Gessler A. Interaction of nitrogen nutrition and salinity in Grey poplar (Populus tremula × alba). Plant Cell Environ. 2007;30:796-811.

65. Wang $L$, Zhou Q, Ding $L$, Sun $Y$. Effect of cadmium toxicity on nitrogen metabolism in leaves of Solanum nigrum L. as a newly found cadmium hyperaccumulator. J Hazard Mater. 2008;154:818-25.

66. Del Campo CP, Garde-Cerdán T, Sánchez AM, Maggi L, Carmona M, Alonso GL. Determination of free amino acids and ammonium ion in saffron (Crocus sativus L.) from different geographical origins. Food Chem. 2009;114:1542-8.

67. Li JY, Fu YL, Pike SM, Bao J, TianW ZY, Chen CZ, Zhang Y, Li HM, Huang J, Li LG, Schroeder JI, Gassmann W, Gong JM. The Arabidopsis nitrate transporter NRT1.8 functions in nitrate removal from the xylem sap and mediates cadmium tolerance. Plant Cell. 2010;22:1633-46.

\section{Publisher's Note}

Springer Nature remains neutral with regard to jurisdictional claims in published maps and institutional affiliations. 